\title{
Synthesis of Thiamine-Modified Bentonite for Pretreatment of Pharmaceutical Wastewater
}

DOI: $10.15255 /$ KUI.2014.005

KUI-13/2015

Original scientific paper

Received February 2, 2014

Accepted May 16, 2014

\author{
H. Shao, ${ }^{a}$ X.-G. Liu, ${ }^{\mathrm{a},}{ }^{*}$ N. Cao, ${ }^{\mathrm{a}}$ J.-G. Li, ${ }^{\mathrm{b}}$ \\ D.-W. Wang, and Z.-F. Zhang \\ anstitute of Environmental and Safety Engineering, Shenyang University of Chemical \\ Technology, 110142 Shenyang, PR China \\ ${ }^{b}$ Institute of Science and Engineering of Materials, Shenyang University of Chemical \\ Technology, 110142 Shenyang, PR China
}

\begin{abstract}
\| Abstract
A series of sodium bentonite and thiamine were used as raw materials to prepare a new adsorbent - thiamine-modified bentonite. The adsorbent was applied in the pretreatment of pharmaceutical wastewater. The optimum preparation conditions of thiamine-modified bentonite were studied. The experiments showed that the removals of COD (chemical oxygen demand) reached $47.98 \%$ under optimal condition. The FTIR results indicated that bentonite has been modified by thiamine. The X-ray diffraction result showed that the interplanar distance of modified bentonite was increased by intercalating thiamine. From the analyses of the SEM photographs, it can be clearly observed that the bentonite, after thiamine insertion reaction, loses its foliated structure and exhibits a rougher surface. Among several isotherm equations, Langmuir and Freundlich adsorption isotherms were investigated. They were widely used to describe equilibrium data for water and wastewater treatment applications. Adsorption isotherms correlate well with the Langmuir isotherm model. Detailed isothermal and kinetic studies show that the modified bentonite removes organic pollutants from pharmaceutical wastewater by physical adsorption processes.
\end{abstract}

$\|$ Keywords

Bentonite, thiamine, pharmaceutical wastewater, pretreatment

\section{Introduction}

The pharmaceutical industry is one of the 12 industries in the State Environmental Protection Plan focusing on governance in China. The pharmaceutical industry accounts for $1.7 \%$ of China's total industrial output, and the pharmaceutical wastewater discharge was about $2 \%$ of total industrial discharges. ${ }^{1}$ As the production processes and drug products are different and characteristic, the composition of pharmaceutical wastewater is complicated. According to the different production processes, pharmaceutical wastewater is divided into fermentation, chemical synthesis, mixing and formulating, biological engineering, extraction, and Chinese traditional medicine. Generally, pharmaceutical wastewater is characterized by complicated elements, intricate species of organic pollutants, high concentrations of suspended substances and ammonia, dark colour, high toxicity, and low ratio of BOD and COD. ${ }^{2}$

At present, many common conventional methods of treatment have been applied for pharmaceutical wastewater. The up-flow anaerobic stage reactor (UASR) was used for treatment of pharmaceutical wastewater containing macrolide antibiotics, and the COD reduction was $70-75 \%{ }^{3}$ The anaerobic treatment was applied to pharmaceutical wastewater of chemical synthesis-based drug. With differ-

*Corresponding author: Master Xianglong Liu

e-mail: westdragon_1@163.com ent treatment processes, the COD removal efficiency was different. $^{4-6}$ Biological treatment was also applied to improve the treatability of the pharmaceutical wastewater at the sources.

However, more than 50 pharmaceutical compounds have been detected over the last years in pharmaceutical wastewater samples. ${ }^{7-11}$ Moreover, many of these pharmaceuticals are designed to be persistent and lipophilic and are not eliminated by wastewater treatment or biodegraded in the environment. The removal rate of pharmaceutical compounds increases significantly after pretreatment. ${ }^{12,13}$

Physicochemical treatment is commonly used in the preprocessing stage and biochemical follow-up stage, and the common methods include coagulation, flotation, adsorption, electrolysis, advanced oxidation technology, and wet air oxidation. Coagulation and sedimentation method of physical treatment is the first choice in physical and chemical processing technology. This method can effectively remove the pollutants and improve the biodegradability of wastewater. For better dispersion, small particles and large specific surface area, bentonite is used for wastewater treatment. ${ }^{14,15}$ The modified bentonites with thiamine as modifier are used for pretreatment of fosfomycin sodium epoxy mother liquor wastewater. This kind of modified bentonite is a new and green adsorbent, which reduces the chemical sludge and salt content. The ion exchange process in modification is shown in Fig. 1.16 


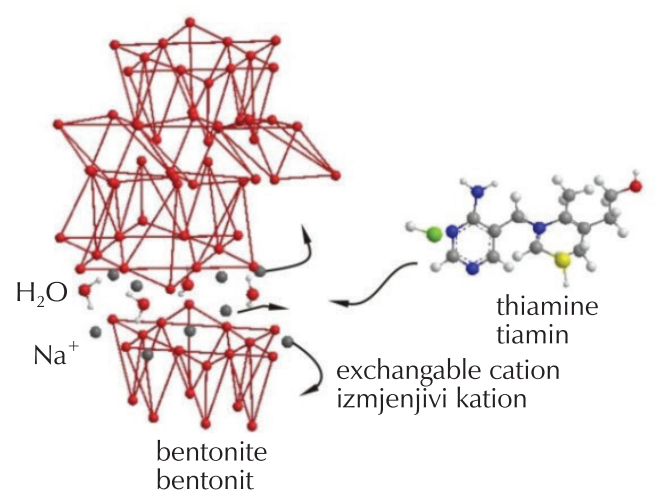

Fig. 1 - The modified reaction of bentonite and thiamine Slika 1 - Reakcija modifikacije bentonita tiaminom

\section{Experiments}

\section{Materials}

Raw material: The sodium bentonite used in the experiments was purchased from Heishan, Liaoning Province, China. The basic properties are shown in Table 1.

The modifier: A certain quantity of thiamine (Guangfu Institute of Fine Chemical, China).

Table 1 - Properties of natural bentonite Tablica 1 - Svojstva prirodnog bentonita

\begin{tabular}{|c|c|}
\hline $\mathrm{pH}$ & $8-9$ \\
\hline $\begin{array}{l}\text { Colloid value } / \mathrm{ml}(15 \mathrm{~g})^{-1} \\
\text { Koloidnost } / \mathrm{ml}(15 \mathrm{~g})^{-1}\end{array}$ & 100 \\
\hline $\begin{array}{l}\text { Cation exchange capacity } / \mathrm{mmol} 100^{-1} \mathrm{~g}^{-1} \\
\text { Kationskoizmjenjivački kapacitet } / \mathrm{mmol} 100^{-1} \mathrm{~g}^{-1}\end{array}$ & 62 \\
\hline $\begin{array}{l}\text { Swelling } / \mathrm{ml} \mathrm{g}^{-1} \\
\text { Bubrenje } / \mathrm{mlg}^{-1}\end{array}$ & 15 \\
\hline $\begin{array}{l}\text { Methylene blue absorption/gg-1 } \\
\text { Apsorpcija metilenskog modrila / } \mathrm{g} \mathrm{g}^{-1}\end{array}$ & $23-25$ \\
\hline
\end{tabular}

Fosfomycin sodium ethylene wastewater (FSE wastewater), a kind of pharmaceutical wastewater, was taken from a pharmaceutical factory in Shenyang, China, with characteristics of high organic concentration, a pungent odour, and $\mathrm{pH}$ of $9-10$. The COD of FSE wastewater was up to $2.060-2.950 \cdot 10^{5} \mathrm{mgl}^{-1}$.

\section{Test method}

The potassium chromate method was applied to determine COD.

\section{Absorption test}

The experiments were performed in a jar test apparatus consisting of six identical beakers of $250 \mathrm{ml}$, each equipped with a stirrer. The FSE wastewater was treated under conditions of various bentonite dosages, modifier concentrations, stirring times, particle sizes, and $\mathrm{pH}$ values. The natural bentonite was added to the beakers with rapid agitation (400 rpm) for some time. Thereafter the particles were allowed to settle for 15 minutes, then the upper solution was taken for COD measurement by the potassium chromate method. The optimal preparing conditions of thiamine-modified bentonite were obtained through single-factor experiments.

\section{Preparation of the modified bentonite}

Thiamine $0.4 \mathrm{~g}$ was dissolved in $1 \mathrm{I}$ hydrochloric acid solution at concentration of $5 \%$ on a magnetic stirrer. Then, $2.4 \mathrm{~g}$ of the sodium bentonite $(\leq 74 \mu \mathrm{m}$ size fraction) was added and the mixture was stirred continuously for 40 minutes. Later, the modified bentonite was separated from the mixture by centrifugation and washed several times using distilled water until a negative result for the presence of chloride was obtained with $\mathrm{AgNO}_{3}$. The modified bentonite was then dried at $30{ }^{\circ} \mathrm{C}$ for $24 \mathrm{~h}$ in a hot air oven, crushed into powder in agate mortars, and stored in moisture-free conditions for further use.

The natural bentonite was modified through the ion exchange reaction using thiamine. Thus, the functional group on the bentonite surface was added. The thiamine-modified bentonite was applied in the pretreatment of FSE wastewater.

\section{Characterization}

Fourier Transform Infrared (FTIR) spectrometer, X-ray diffraction and scanning electron microscopy (SEM) were used for characterization on natural bentonite and modified bentonite.

FTIR: The FTIR was used to identify the surface functional groups of two bentonites.

The FTIR spectra of thiamine bentonite samples were recorded in the transmission mode at room temperature by means of the 470 FT Thereto Nicolet instrument using the $\mathrm{KBr}$ pellet technique $(1: 20)$ with the resolution of $2 \mathrm{~cm}^{-1}$. The $\mathrm{KBr}$ was dried at $200{ }^{\circ} \mathrm{C}$ for $24 \mathrm{~h}$. Then $560 \mathrm{mg}$ of $\mathrm{KBr}$ was homogenized with the bentonite sample in a ball grinder. The tablets (radius $1 \mathrm{~cm}$ and thickness $0.1 \mathrm{~cm}$ ) were prepared using the hydraulic press.

X-ray diffraction: The interplanar distance of two bentonites was measured by X-ray diffraction.

The X-ray diffraction measurements were performed using a Brook D8-Advance instrument (Germany). The conditions of these measurements were as follows: $\mathrm{Cu} K_{\alpha}$ radiation, Ni filter for wavelength discrimination, pulse height analyser, scintillation detector, divergence slit $0.3^{\circ}$, receiving slit $0.15^{\circ}$, range of $2 \theta 3-30^{\circ}$, step size $0.02^{\circ}$, and count time per step $20 \mathrm{~s}$.

SEM: The bentonite powders were measured by a JSM6360LV SEM with High-Low vacuum (JEOL). The bentonites were enlarged by certain multiples. The three-dimensional surface conformation of natural bentonites and modified bentonites was observed. 


\section{Adsorption process of FSE wastewater}

The $0.3 \mathrm{~g}$ of modified bentonite was mixed with $200 \mathrm{ml}$ of wastewater sample at three different temperatures and $\mathrm{pH}=3$. Then the mixture was stirred for 50 minutes and left to set. The COD value was measured by the potassium dichromate method (Chinese national standards GB11941-89). The amount of organic pollutants adsorption was calculated by the following mass-balance equation:

$$
q_{\mathrm{e}}=\left(C_{0}-C_{\mathrm{e}}\right) \cdot \mathrm{V} / \mathrm{m}
$$

$q_{\mathrm{e}}$ - equilibrium adsorption capacity, $\mathrm{C}_{0}$ - initial COD value of FSE wastewater, $C_{e}$ - equilibrium COD value of FSE wastewater, $V$ - volume of FSE wastewater, $m$ - mass of adsorbent.

The nonlinear and linear forms of Langmuir isotherm equation were given in the following equations: ${ }^{17}$

$$
\begin{aligned}
q_{\mathrm{e}} & =q_{\max } C_{\mathrm{e}} K_{\mathrm{L}} /\left(1+C_{\mathrm{e}} K_{\mathrm{L}}\right) \\
1 / q_{\mathrm{e}} & =1 / q_{\max }+1 /\left(K_{\mathrm{L}} q_{\max } C_{\mathrm{e}}\right)
\end{aligned}
$$

$q_{\max }$ - maximum adsorption capacity of the adsorbent; $K_{\mathrm{L}}$ - Langmuir equilibrium constant.

The nonlinear and linear forms of Freundlich isotherm equation were given in the following equations: ${ }^{18}$

$$
\begin{gathered}
q_{\mathrm{e}}=K_{\mathrm{F}} C_{\mathrm{e}}^{1 / n} \\
\log \left(q_{\mathrm{e}} / \mathrm{mgg}^{-1}\right)=\log K_{\mathrm{F}}+1 / n \log \left(C_{\mathrm{e}} / \mathrm{mgl}^{-1}\right)
\end{gathered}
$$

$q_{\mathrm{e}}-$ equilibrium adsorption capacity; $C_{\mathrm{e}}-$ equilibrium COD value of FSE wastewater; $K_{\mathrm{F}}$ - characteristic constant of Freundlich model related to the adsorption capacity; $n$ - parameter characterizing the heterogenity of the system.

The thermodynamic parameters of the adsorption, i.e. the standard Gibbs energy $\Delta G^{\ominus}$, standard enthalpy $\Delta H^{\ominus}$, and entropy $\Delta S^{\ominus}$, were calculated using the Van't Hoff equation.

$$
\begin{gathered}
\Delta \mathrm{G}^{\ominus}=-R T \ln K_{\mathrm{ads}} \\
\ln K_{\mathrm{ads}}=-\Delta H^{\ominus} / R T+\Delta S^{\ominus} / R
\end{gathered}
$$

where, the slope and intercept of the plot of $\ln K_{\text {ads }}$ versus $1 / T$ were used to determine the $\Delta H^{\ominus}$ and $\Delta S^{\ominus} . R$ is the gas constant and $T$ is the absolute temperature.

\section{Results and discussion}

\section{Optimal conditions of modified bentonite preparation}

\section{Effect of bentonite dosage on COD removal rate}

The influence of different bentonite dosages on adsorption is shown in Fig. 2. The COD removal rate increased with an increase in the bentonite dosage up to $4 \mathrm{gl}^{-1}$. When the bentonite dosage was higher than $4 \mathrm{gl}^{-1}$, the COD removal rate dropped.

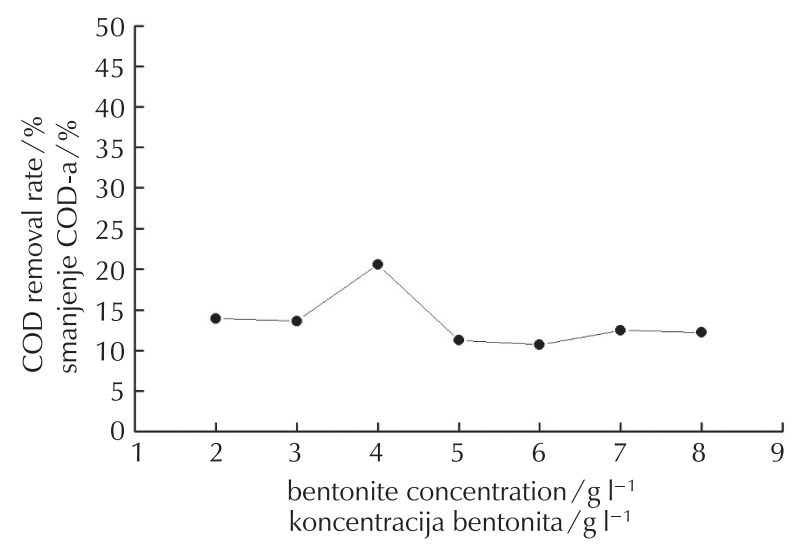

Fig. 2 - Effect of bentonite dosage on COD removal rate Slika 2 - Učinak koncentracije bentonita na smanjenje COD-a

The bentonite was the matrix of modified bentonite. The greater the matrix, the more modified bentonite was prepared. But the bentonite could not be modified by thiamine if the bentonite surpassed the exchanged capability.

\section{Effect of the modifier concentration on COD removal rate}

The effect of the modifier concentration on COD removal rate is shown in Fig. 3. The COD removal rate increased gradually with a modifier concentration in the range of $0-5 \mathrm{gl}^{-1}$. The COD removal rate was close to a stable equilibrium state when the modifier concentration was in the range of $5 \mathrm{gl}^{-1}$ to $13 \mathrm{gl}^{-1}$. Then the COD removal rate decreased.

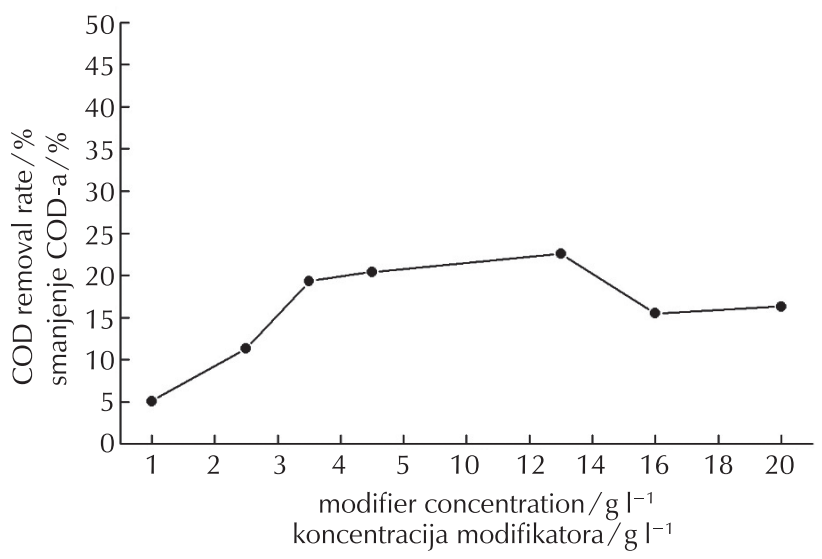

Fig. 3 - Effect of the modifier concentration on COD removal rate

Slika 3 - Učinak koncentracije modifikatora na smanjenje COD-a

The COD value of FSE wastewater was $2.060-2.950 \cdot 10^{5} \mathrm{mg} \mathrm{l}^{-1}$ which meant that a large number of the organic particles existed in the processing solution. The organic particles, bentonite and thiamine, were in a congested state. The positive charge of bentonite and negative charge of thiamine interacted as the function of irregular Brownian motion. Therefore, the bentonite was modified by thiamine on the surface or in the interlaminar 
region. The organic particles were adsorbed by the modified bentonite (at modifier concentration of $0-5 \mathrm{gl}^{-1}$ ). When the flocculation particles were large enough, the collision force effect between particles was not obvious. Then Brownian motion tended to balance (at modifier concentration in the range of $5-13 \mathrm{~g} \mathrm{l}^{-1}$ ). When the modifier concentration increased continually, the excess thiamine existed with the form of organic matter in wastewater. The COD removal rate decreased (at modifier concentration higher than $13 \mathrm{gl}^{-1}$ ).

\section{Effect of stirring time on COD removal rate}

The dependence of COD removal rate on adsorption time is stated in Fig. 4. The dosage of the modified bentonite was $5 \mathrm{~g} \mathrm{I}^{-1}$. Firstly, the COD removal rate increased, then achieved a balance, and finally decreased when stirring time ranged from 20 to 140 minutes. The COD removal rate reached the maximum at stirring time of 40 minutes.

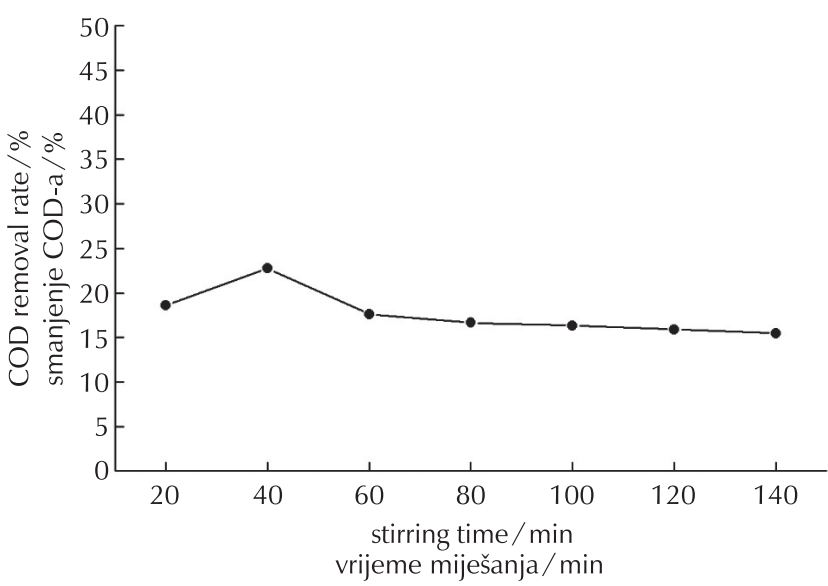

Fig. 4 - Effect of stirring time on COD removal rate

Slika 4 - Učinak vremena miješanja na smanjenje COD-a

Using mechanical rabble, the bentonite is modified by thiamine sufficiently. As displayed in Fig. 4, the removal capacity of the modified bentonite increased with the increase in stirring time and reached a maximum value at 40 minutes. With a further increase in stirring time, there was a steady decrease in the percentage of adsorption.

\section{Effect of particle size on COD removal rate}

The particle size in the range of $0.063-0.45 \mathrm{~mm}$ presented a slight effect on COD removal (Fig. 5). The dosage of the modified bentonite was $5 \mathrm{gl}^{-1}$. A peak COD removal effect was observed at particle size of $0.076 \mathrm{~mm}$.

The shape of modified bentonite in wastewater was expressed by particle size. The aggregates could not form when particle size was too small (smaller than $0.076 \mathrm{~mm}$ ). The specific surface area decreased when particle size was too large. Therefore, the activity and adsorption ability decreased at particle size larger than $0.076 \mathrm{~mm}$. The flocculation ability of modified bentonite at particle size of $0.076 \mathrm{~mm}$ was the highest.

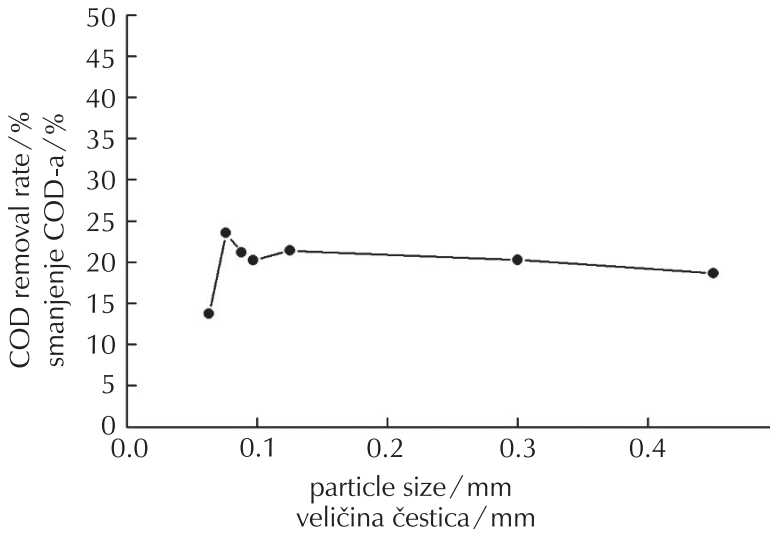

Fig. 5 - Effect of particle size on COD removal rate Slika 5 - Učinak veličine čestica na smanjenje COD-a

The shape of modified bentonite in wastewater was expressed by particle size. The aggregates could not form when particle size was too small (smaller than $0.076 \mathrm{~mm}$ ). The specific surface area decreased when particle size was too large. Therefore, the activity and adsorption ability decreased at particle size larger than $0.076 \mathrm{~mm}$. The flocculation ability of modified bentonite at particle size of $0.076 \mathrm{~mm}$ was the highest.

\section{Effect of the modifier $\mathrm{pH}$ on COD removal rate}

The dosage of the modified bentonite was $5 \mathrm{gl}^{-1}$. From the dependency demonstrated in Fig. 6, it was clear that the modifier $\mathrm{pH}$ greatly influenced COD removal rate. At $\mathrm{pH}$ of $2-3$, the COD removal rate showed an upward trend and the removal efficiency was very good. However, with the further increase in $\mathrm{pH}$ value, the COD removal rate decreased.

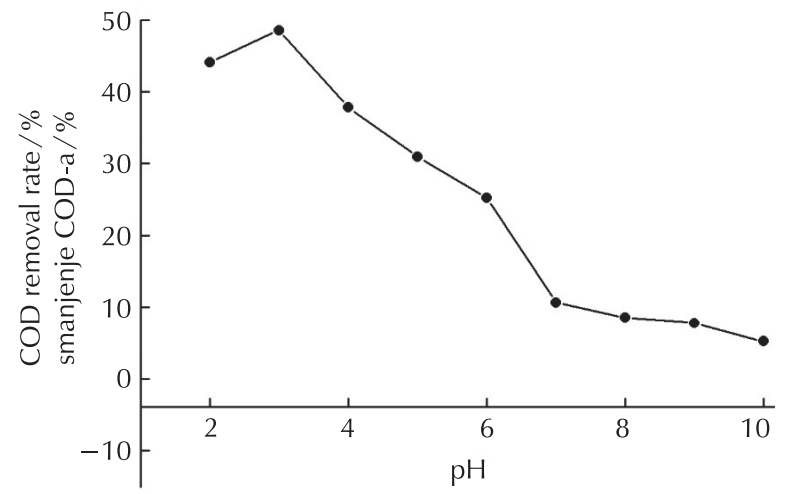

Fig. 6 - Effect of $\mathrm{pH}$ on COD removal rate Slika 6 - Učinak pH na smanjenje COD-a

The adsorption capability of modified bentonite was impacted significantly by the physical and chemical properties of the thiamine. The modifier $\mathrm{pH}$ was decisive to physical and chemical properties of thiamine. Thiamine was stable at acidic $\mathrm{pH}$. In addition, at low $\mathrm{pH}$, the bentonite 
surface was positively charged, which could be beneficial to the modification process due to the ion exchange. The molecular structure of thiamine was unstable in the alkaline solution, and it was susceptible to oxidation and decomposition. As illustrated in the figure, when $\mathrm{pH}$ was 2 , the removal efficiency reached the maximum.

Through optimization of modified-bentonite preparation conditions, the COD removal rate of pharmaceutical wastewater reached $47.98 \%$. With a higher concentration of organic contaminant in pharmaceutical wastewater, a multi-step treatment process was needed. The adsorption process on thiamine-modified bentonite could be applied in the pretreatment process.

\section{Characterization on sodium bentonite and modified bentonite}

FTIR: Each functional group of bentonite was unique and corresponded to the fundamental vibrational bands of the infrared spectrum, respectively. The spectra of natural and modified bentonite are presented in Fig. 7.

The functional groups of two bentonites and their corresponding wave number are summarized in Table 2.

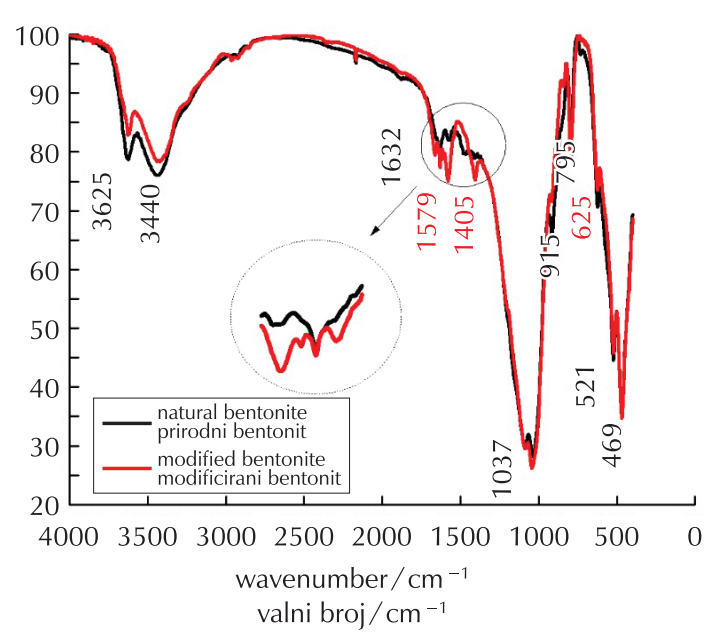

Fig. 7 - FTIR of two bentonites (A. natural bentonite; B. modified bentonite)

Slika 7 - FTIR dvaju bentonita (A - prirodni bentonit, B - modificirani bentonit)

The basic infrared spectra of natural bentonite still existed in modified bentonite. The interlayer structure of two sili-

Table 2 - Functional groups of two bentonites

Tablica 2 - Funkcijske skupine dvaju bentonita

\begin{tabular}{|c|c|c|}
\hline \multirow{2}{*}{ Peak assignment } & $\begin{array}{l}\text { Natural bentonite } \\
\text { Prirodni bentonit }\end{array}$ & $\begin{array}{l}\text { Modified bentonite } \\
\text { Modificirani bentonit }\end{array}$ \\
\hline & \multicolumn{2}{|c|}{$\begin{array}{l}\text { Wavenumber } / \mathrm{cm}^{-1} \\
\text { Valni broj } / \mathrm{cm}^{-1}\end{array}$} \\
\hline $\begin{array}{l}\mathrm{Si}-\mathrm{OH}-\mathrm{Al} \text { stretch } \\
\text { istezanje } \mathrm{Si}-\mathrm{OH}-\mathrm{Al}\end{array}$ & 3625 & 3627 \\
\hline $\begin{array}{l}\mathrm{O}-\mathrm{H} \text { stretch } \\
\text { istezanje } \mathrm{O}-\mathrm{H}\end{array}$ & 3440 & 3424 \\
\hline $\begin{array}{l}\mathrm{O}-\mathrm{H} \text { bend } \\
\text { svijanje } \mathrm{O}-\mathrm{H}\end{array}$ & 1632 & 1632 \\
\hline $\begin{array}{l}\mathrm{N}-\mathrm{H} \text { (primary amines) } \\
\mathrm{N}-\mathrm{H} \text { (primarni amini) }\end{array}$ & - & 1579 \\
\hline $\begin{array}{l}\mathrm{C}-\mathrm{N} \text { stretch } \\
\text { istezanje } \mathrm{C}-\mathrm{N}\end{array}$ & - & 1405 \\
\hline $\begin{array}{l}\mathrm{Si}-\mathrm{O} \text { stretch } \\
\text { istezanje } \mathrm{Si}-\mathrm{O}\end{array}$ & 1037 & 1044 \\
\hline $\begin{array}{l}\mathrm{Al}-\mathrm{Al}-\mathrm{OH} \text { bend } \\
\text { svijanje } \mathrm{Al}-\mathrm{Al}-\mathrm{OH}\end{array}$ & 915 & 917 \\
\hline $\begin{array}{l}\mathrm{Si}-\mathrm{O} \text { bend } \\
\text { svijanje } \mathrm{Si}-\mathrm{O}\end{array}$ & 795 & 796 \\
\hline $\begin{array}{l}\mathrm{N}-\mathrm{H} \text { plane deformation } \\
\text { ravninska deformacija } \mathrm{N}-\mathrm{H}\end{array}$ & - & 625 \\
\hline $\begin{array}{l}\mathrm{Al}-\mathrm{O}-\mathrm{Si} \text { bend } \\
\text { svijanje } \mathrm{Al}-\mathrm{O}-\mathrm{Si}\end{array}$ & 521 & 520 \\
\hline $\begin{array}{l}\mathrm{Si}-\mathrm{O}-\mathrm{Si} \text { bend } \\
\text { svijanje } \mathrm{Si}-\mathrm{O}-\mathrm{Si}\end{array}$ & 469 & 468 \\
\hline
\end{tabular}


con-oxygen tetrahedral layers and one aluminum-oxygen octahedral layer remained unchanged. By comparing the FT-IR spectra of the natural and modified bentonite, the intensities increase apparently at $1579 \mathrm{~cm}^{-1}, 1405 \mathrm{~cm}^{-1}$ and $625 \mathrm{~cm}^{-1}$. There were function groups of $\mathrm{N}-\mathrm{H}, \mathrm{C}-\mathrm{N}$ and $\mathrm{N}-\mathrm{H}$. Nitrogen element was excluded from natural bentonite. Thus, the new functional groups were obtained from the ion exchange between natural bentonite and thiamine. The modified function of natural bentonite was effective.

X-ray diffraction: The X-ray diffraction was mainly used to study the interplanar distance of the modified bentonite. The X-ray diffractograms of the sodium bentonite and modified bentonite are shown in Fig. 8.

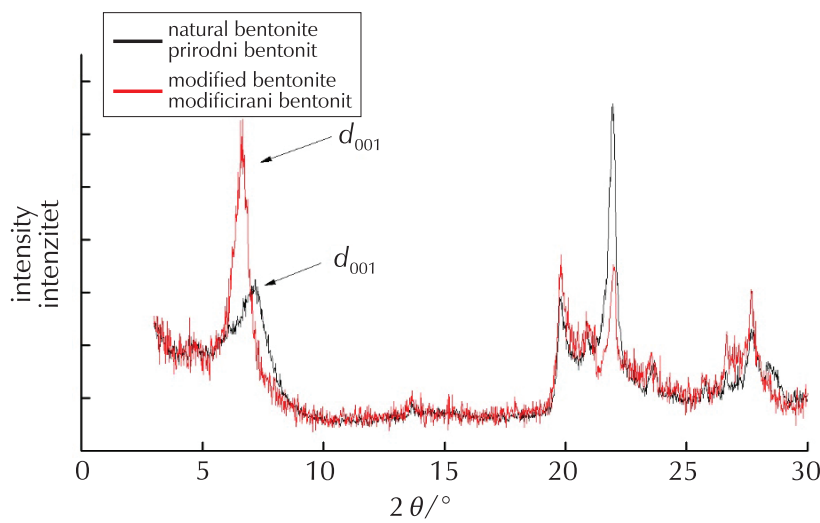

Fig. 8 - X-ray diffraction patterns of two bentonites Slika 8 - Rendgenogrami dvaju bentonita

The small angle $\left(3^{\circ}-10^{\circ}\right)$ of XRD diffraction peaks could be used to study the structure of mesoporous materials. The angle $2 \theta$ was measured and the interplanar distance $d$ was calculated according to $\mathrm{X}$-ray diffraction spectrum and Bragg equation: $2 d \sin \theta=n \lambda$. The interplanar distance of sodium bentonite was $12.2692 \mathrm{~nm}$, and the interplanar distance of modified bentonite was $13.3407 \mathrm{~nm}$.

The anion of thiamine has exchanged the cation on the surface of bentonite. The thiamine molecules entered the layer space to a certain extent. This indicated the presence of the thiamine molecule between the silicate layers.

SEM: The samples of sodium bentonite and modified bentonite were observed using a SEM, as shown in Fig. 9.
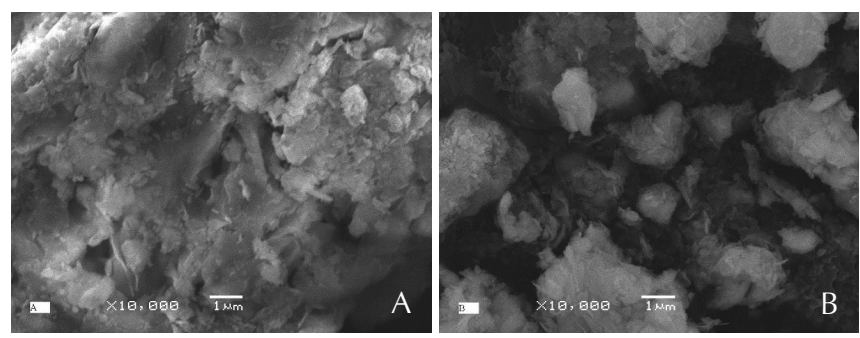

Fig. 9 - SEM images of two bentonites (A. sodium bentonite; B. modified bentonite)

Slika 9 - SEM-slike dvaju bentonita (A - natrijev bentonit, B modificirani bentonit)
By analysing the SEM photographs, it was clearly observed that the bentonite lost its foliated structure and gained a rougher surface after the thiamine insertion reaction.

\section{Adsorption isotherms}

The interactions between adsorbate and adsorbent could be described by adsorption isotherms. The equilibrium data of FSE wastewater adsorption along with the fitting models are shown in Fig. 10.
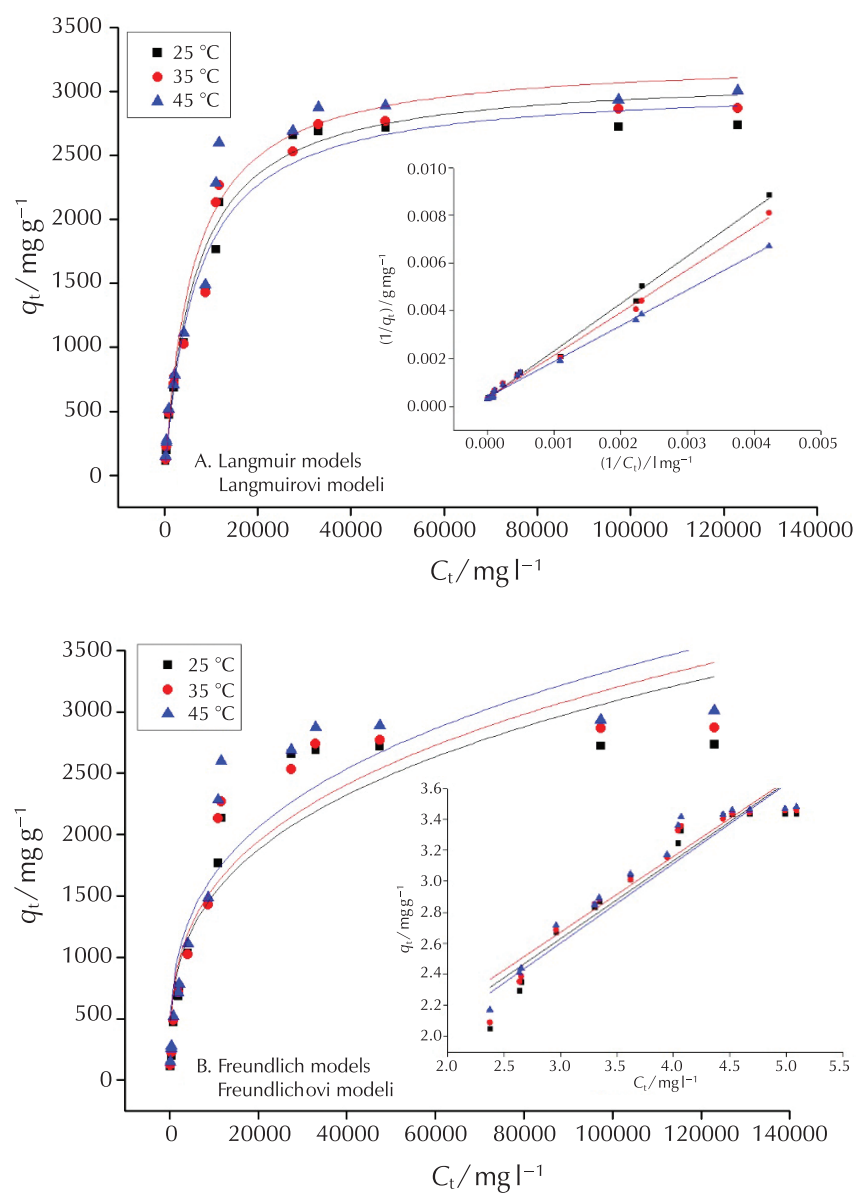

Fig. 10 - Adsorption isotherms of FSE wastewater adsorption onto modified bentonite and the fitting model (inset is the linear form of models)

Slika 10 - Adsorpcijske izoterme adsorpcije iz otpadne vode s FSE-om na modificirani bentonit i prilagođeni model (umetnut je linearni model)

The temperature-dependent parameters of Langmuir models obtained from the fitting procedure are summarized in Table 3. The data indicates that Langmuir models could represent the equilibrium data fairly well $\left(R^{2}\right.$ of Langmuir $>R^{2}$ of Freundlich). The organic pollutant of FSE wastewater was adsorbed easily onto the surface and interlaminar of the bentonite, and monolayer adsorption was formed. Then the molecular movement was more and more regular. 
Table 3 - Fitted parameters of temperature dependent form of two isotherm models Tablica 3 - Prilagođeni parametri dvaju izotermnih modela ovisnih o temperaturi

\begin{tabular}{|c|c|c|c|c|c|}
\hline \multicolumn{6}{|c|}{$\begin{array}{l}\text { Langmuir model } \\
\text { Langmuirov model }\end{array}$} \\
\hline \multirow{2}{*}{$\begin{array}{l}\text { temperature } \\
\text { temperatura }\end{array}$} & \multirow{2}{*}{$\begin{array}{l}\text { equation } \\
\text { jednadžba }\end{array}$} & \multicolumn{2}{|c|}{$q_{0}$} & $K_{\mathrm{L}}$ & \multirow{2}{*}{$R^{2}$} \\
\hline & & \multicolumn{2}{|c|}{$\mathrm{mgg}^{-1}$} & $\operatorname{lmg}^{-1}$ & \\
\hline \multirow{2}{*}{$25^{\circ} \mathrm{C}$} & \multirow{2}{*}{$q_{\mathrm{e}}=\frac{0.4711 C_{\mathrm{e}}}{1+0.0001504 C_{\mathrm{e}}}$} & \multirow{2}{*}{\multicolumn{2}{|c|}{31.32}} & \multirow{2}{*}{0.0001504} & \multirow{2}{*}{0.9795} \\
\hline & & & & & \\
\hline \multirow{2}{*}{$35{ }^{\circ} \mathrm{C}$} & \multirow{2}{*}{$q_{e}=\frac{0.5250 C_{e}}{1+0.0001609 C_{e}}$} & \multirow{2}{*}{\multicolumn{2}{|c|}{32.62}} & \multirow{2}{*}{0.0001609} & \multirow{2}{*}{0.9675} \\
\hline & & & & & \\
\hline \multirow{2}{*}{$45^{\circ} \mathrm{C}$} & \multirow{2}{*}{$q_{\mathrm{e}}=\frac{0.4424 C_{\mathrm{e}}}{1+0.0001451 C_{\mathrm{e}}}$} & \multirow{2}{*}{\multicolumn{2}{|c|}{30.48}} & \multirow{2}{*}{0.0001451} & \multirow[b]{2}{*}{0.9810} \\
\hline & & & & & \\
\hline \multicolumn{6}{|c|}{$\begin{array}{l}\text { Freundlich model } \\
\text { Freundlichov model }\end{array}$} \\
\hline \multirow{2}{*}{$\begin{array}{l}\text { temperature } \\
\text { temperatura }\end{array}$} & \multirow{2}{*}{$\begin{array}{l}\text { equation } \\
\text { jednadžba }\end{array}$} & \multirow{2}{*}{$1 / n$} & & $K_{\mathrm{F}}$ & \multirow{2}{*}{$R^{2}$} \\
\hline & & & & $g^{-1} /\left(\mathrm{mg}^{-1}\right)^{-n}$ & \\
\hline $25^{\circ} \mathrm{C}$ & $q_{\mathrm{e}}=87.82 \mathrm{C}_{\mathrm{e}}^{0.3091}$ & 0.3091 & & 87.82 & 0.8609 \\
\hline $35^{\circ} \mathrm{C}$ & $q_{\mathrm{e}}=91.85 C_{\mathrm{e}}^{0.3082}$ & 0.3082 & & 91.85 & 0.8644 \\
\hline $45^{\circ} \mathrm{C}$ & $q_{\mathrm{e}}=104 C_{\mathrm{e}}^{0.3011}$ & 0.3011 & & 104.27 & 0.8404 \\
\hline
\end{tabular}

In order to further investigate the adsorption mechanism, the adsorption thermodynamic parameters of organic contaminants on the modified bentonite were calculated, and are listed in Table 4.

Table 4 - Adsorption thermodynamic parameters

Tablica 4 - Termodinamički parametri adsorpcije

\begin{tabular}{c|c|c|c|c}
\hline$T / K$ & $k_{0} / \mathrm{kg}^{-1}$ & $\Delta \mathrm{G}^{\ominus} / \mathrm{kJ} \mathrm{mol}^{-1}$ & $\Delta H^{\ominus} / \mathrm{kJ} \mathrm{mol}^{-1}$ & $\begin{array}{c}\Delta \mathrm{S}^{\ominus} / \\
\mathrm{J} \mathrm{Kmol}\end{array}$ \\
\hline 298 & 0.0054 & -12.9363 & & 57.28658 \\
308 & 0.0056 & -13.2773 & 4.1351 & 56.53377 \\
318 & 0.0060 & -13.5259 & & 55.53774 \\
\hline
\end{tabular}

The adsorption reaction was an endothermic process as the $\Delta H^{\ominus}$ value was greater than zero. So the elevated temperature was beneficial to the adsorption reaction. When the enthalpy changed in the range of $0-63 \mathrm{~kJ} \mathrm{~mol}^{-1}$, the adsorption reaction was a physical one. And the heat of adsorption caused by the molecular forces ranged from 4 to $10 \mathrm{~kJ} \mathrm{~mol}^{-1}$, and the molecular force was a van der Waals force. Hence, it could be said that the adsorption of FSE wastewater on modified bentonite is a physical adsorption. Meanwhile, the $\Delta S^{\ominus}$ value decreased with the rise in temperature. This was in line with the rule of polymer entropy that decreased by adsorption reaction.

\section{Conclusion}

A new adsorption material was synthesized using sodium bentonite and thiamine, the optimal preparation conditions of modified bentonite were: bentonite dosage of $4 \mathrm{gl}^{-1}$, modifier concentration of $13 \mathrm{~g} \mathrm{I}^{-1}$, stirring for 40 minutes, particle size of $0.076 \mathrm{~mm}$, and modifier $\mathrm{pH}$ 3. The preparation technology was non-toxic with no secondary pollution. The thiamine-modified bentonite was applied in the pretreatment process of pharmaceutical wastewater and the COD removal rate reached $47.98 \%$.

FTIR analysis results of modified bentonite showed that all characteristic peaks of natural bentonite had been retained, and the interlayer structures of two silicon-oxygen tetrahedral layers and one aluminum-oxide octahedral layer were constant. Three new characteristic peaks were observed at $1579 \mathrm{~cm}^{-1}, 1425 \mathrm{~cm}^{-1}$, and $625 \mathrm{~cm}^{-1}$. These peaks were all amino functional groups and originated from thiamine. Therefore, the natural bentonite was modified by ionization of thiamine. Analysis results of X-ray diffraction of modified bentonite showed that the interplanar distance increased at varying degrees, the thiamine had entered the interplanar space of bentonite, which improved the adsorption performance. The SEM characterization results showed that the modified bentonite clumps were smaller with higher dispersion and clear structure hole, the adsorption performance increased.

Adsorption thermodynamic processes of organic pollutants in FSE wastewater on modified bentonite were employed to correlate Langmuir models. The adsorption reaction was a physical adsorption process. Temperature increase was conducive to the reaction. 


\section{ACKNOWLEDGEMENTS}

I would like to show my deepest gratitude to my supervisor, Dr. Hong Shao, a respectable, responsible, and resourceful scholar, who has provided me with valuable guidance in every stage of the writing of this thesis. Without her enlightening instruction, impressive kindness and patience, I could not have completed my thesis.

\section{List of symbols and abbreviations Popis simbola i kratica}

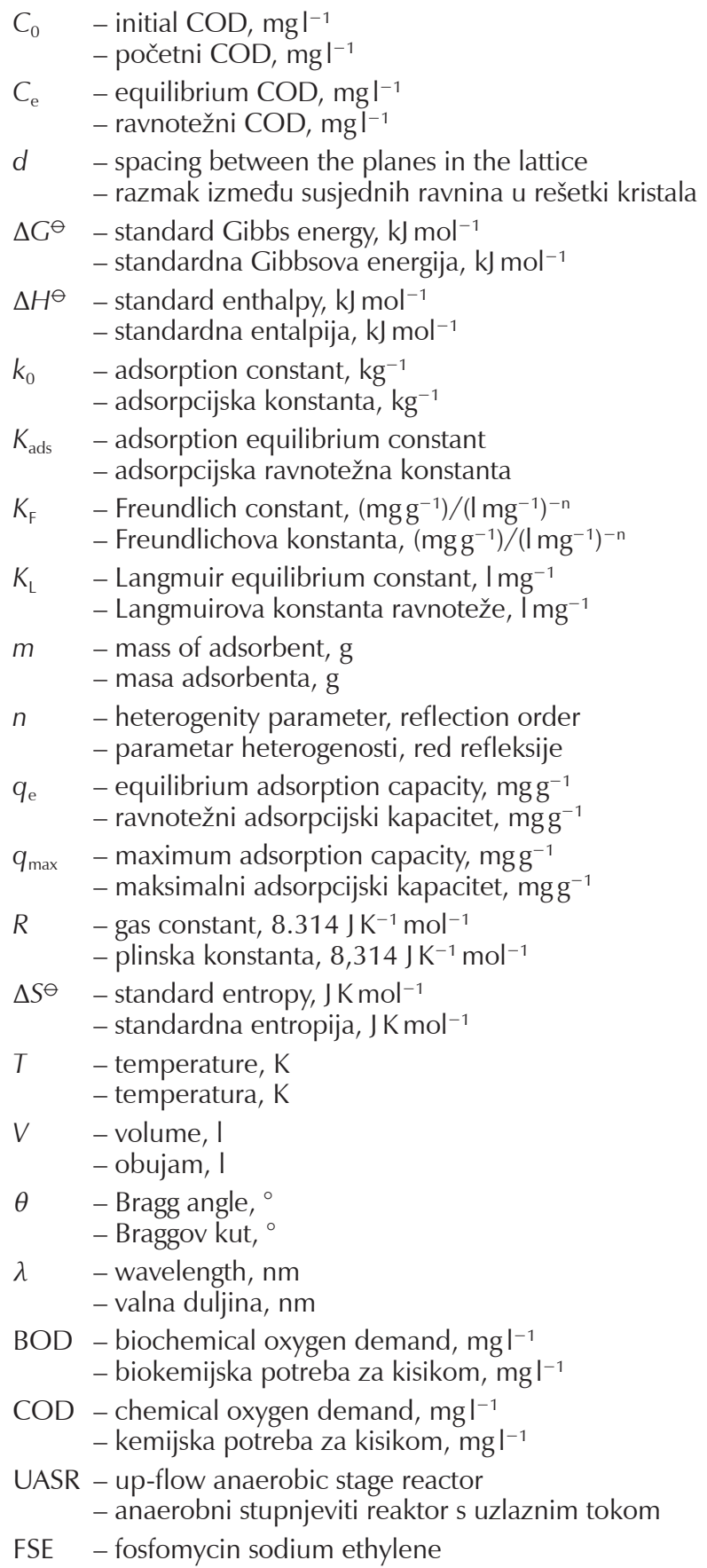

\section{References Literatura}

1. H. R. Sun, X. L. Wang, Research progress of pharmaceutical industrial water pollutant environmental risk warning, Environ. Sci. Technol. 12 (2011) 139-142.

2. B. Ferrari, N. Paxeus, R. Lo Giudice, A. Pollio, J. Garric, Ecotoxicological impact of pharmaceuticals found in treated wastewaters: Study of carbamazepine, clofibric acid, and diclofenac, Ecotox. Environ. Safe. 55 (2003) 359-370, http:// dx.doi.org/10.1016/S0147-6513(02)00082-9.

3. S. Chelliapan, T. Wilby, P. J. Sallis, Performance of an up-flow anaerobic stage reactor (UASR) in the treatment of pharmaceutical wastewater containing macrolide antibiotics, Water Res. 40 (2006) 507-516, http://dx.doi.org/10.1016/j. watres.2005.11.020.

4. Y. A. Oktem, O. Ince, P. Sallis, T. Donnelly, B. K. Ince, Anaerobic treatment of a chemical synthesis-based pharmaceutical wastewater in a hybrid upflow anaerobic sludge blanket reactor, Bioresource Technol. 99 (2008) 1086-1096, http:// dx.doi.org/10.1016/j.biortech.2007.02.036.

5. S. Chelliapan, T. Wilby, A. Yuzir, P. J. Sallis, Influence of organic loading on the performance and microbial community structure of an anaerobic stage reactor treating pharmaceutical wastewater, Desalination 271 (2011) 257-264, http:// dx.doi.org/10.1016/j.desal.2010.12.045.

6. Z. B. Chen, H. C. Wang, N. Q. Ren, M. H. Cui, S. K. Nie, D. X. Hu, Simultaneous removal and evaluation of organic substrates and $\mathrm{NH}_{3}-\mathrm{N}$ by a novel combined process in treating chemical synthesis-based pharmaceutical wastewater, J. Hazard. Mater. 197 (2011) 49-59, http://dx.doi. org/10.1016/j.jhazmat.2011.09.053.

7. N. Lindqvista, T. Tuhkanenb, L. Kronberga, Occurrence of acidic pharmaceuticals in raw and treated sewage and in receiving water, Water Res. 39 (2005) 2219-2228, http:// dx.doi.org/10.1016/j.watres.2005.04.003.

8. T. A. Ternes, Occurrence of drugs in German sewage treatment plants and rivers, Water Res. 32(11) (1998) 32453260, http://dx.doi.org/10.1016/S0043-1354(98)00099-2.

9. H. R. Buser, M. D. Muller, Occurrence of the pharmaceutical drug clofibric acid and the herbicide mecoprop in various Swiss Lakes and in the North Sea, Environ. Sci. Technol. 32(1) (1998) 188-192, http://dx.doi.org/10.1021/es9705811.

10. W. H. Xu, G. Zhang, S. C. Zou, X. D. Li, Y. C. Liu, Determination of selected antibiotics in the Victoria Harbour and the Pearl River, South China using high-performance liquid chromatography-electro spray ionization tandem mass spectrometry, Environ. Pollut. 145 (2007) 672-679, http:// dx.doi.org/10.1016/j.envpol.2006.05.038.

11. W. Xu, G. Zhang, X. Li, S. Zou, P. Li, Z. Hu, J. Li, Occurrence and elimination of antibiotics at four sewage treatment plants in the Pearl River Delta (PRD), South China, Water Res. 41(19) (2007) 4526-4534, http://dx.doi.org/10.1016/j. watres.2007.06.023.

12. M. Rosen, T. Welander, A. Lofqvist, J. Holmgren, Development of a new process for treatment of a pharmaceutical wastewater, Water Sci. Technol. 37(9) (1998) 251-258, http://dx.doi.org/10.1016/S0273-1223(98)00295-9.

13. T. M. LaPara, C. H. Nakastu, L. M. Pantea, J. E. Alleman, Stability of the bacterial communities supported by a seven-stage biological process treating pharmaceutical wastewater as revealed by PCR-DGGE, Water Res. 36 (2002) 638-646, http://dx.doi.org/10.1016/S0043-1354(01)00277-9.

14. H. Shao, N. Cao, Adsorption of $\mathrm{Cr}(\mathrm{VI})$ on Fe-Ni modified bentonites, Environ. Eng. Manage. 7 (2011a) 875-879. 
15. H. Shao, N. Cao, Characterization and application in pretreatment of landfill leachate on modified bentonites, Adv. Mater. Res. 287-290 (2011b) 1675-1679, http://dx.doi. org/10.4028/www.scientific.net/AMR.287-290.1675.

16. M. Majdan, S. Pikus, A. Gajowiak, D. Sternik, E. Zieba, Uranium sorption on bentonite modified by octadecyltrimethylammonium bromide, J. Hazard. Mater. 184 (2010) 662670, http://dx.doi.org/10.1016/j.jhazmat.2010.08.089.

17. A. K. Rahardjo, M. J. J. Susanto, A. Kurniawan, N. Indraswati,
Modified ponnorogo bentonite for the removal of ampicillin from wastewater, J. Hazard. Mater. 190 (2011) 1001-1008, http://dx.doi.org/10.1016/j.jhazmat.2011.04.052.

18. M. Randelovic, M. Purenovic, A. Zarubica, J. Purenovic, B. Matovic, M. Momcilovic, Synthesis of composite by application of mixed Fe, Mg(hydr) oxides coatings onto bentonite- A use for the removal of $\mathrm{Pb}$ (II) from water, J. Hazard. Mater. 190-200 (2012) 367-374, http://dx.doi.org/10.1016/j.jhazmat.2011.11.025.

\section{SAŽETAK \\ Modificiranje bentonita tiaminom za predobradu otpadne vode iz farmaceutske industrije \\ Hong Shao, ${ }^{a}$ Xianglong Liu, a, ${ }^{*}$ Ning Cao, ${ }^{a}$ \\ Jianguang Li, bawei Wang a i Zhifang Zhang a}

Bentonit je modificiran tiaminom i primijenjen u predobradi vode iz farmaceutske industrije. Proučavani su optimalni uvjeti pripreme bentonita. Eksperimenti su pokazali da se pod optimalnim uvjetima kemijska potreba za kisikom (COD) smanjuje za 47,98 \%. FTIR ukazuje na modifikaciju bentonita tiaminom, a rendgenska difrakcija na povećanje udaljenosti među slojevima bentonita interkaliranjem tiamina. Bentonit nakon interkalacije tiamina gubi lisnatu strukturu i pokazuje grublju površinu. Od nekoliko izotermnih jednadžbi, istraživane su Langmuirove i Freundlichove adsorpcijske izoterme. One se široko primjenjuju za opisivanje ravnotežnih podataka u obradi i pročišćavanju voda. Adsorpcijske izoterme dobro koreliraju s Langmuirovim izotermnim modelom. Detaljne izotermne i kinetičke studije pokazuju da modificirani bentonit fizičkim adsorpcijskim procesima uklanja organske onečišćujuće tvari iz farmaceutskih otpadnih voda.

Ključne riječi

Bentonit, tiamin, farmaceutske otpadne vode, predobrada

a Institute of Environmental and Safety Engineering, Shenyang University of Chemical Technology, Shenyang 110142 Kina

b Institute of Science and Engineering of Materials, Shenyang University of Chemical Technology, Shenyang 110142 Kina

Izvorni znanstveni rad Prispjelo 2. veljače 2014. Prihvaćeno 16. svibnja 2014. 